\title{
Association of Pigmentation Related-Genes Polymorphisms and Geographic Environmental Variables in the Chinese population
}

\section{Yuxin Wang ( $\nabla$ c21lab1112@163.com)}

Nanchang University

\section{Research}

Keywords: association study, polymorphisms, environmental factors, selection pressure

Posted Date: December 4th, 2020

DOI: https://doi.org/10.21203/rs.3.rs-120285/v1

License: (1) (1) This work is licensed under a Creative Commons Attribution 4.0 International License. Read Full License

Version of Record: A version of this preprint was published at Hereditas on July 8th, 2021. See the published version at https://doi.org/10.1186/s41065-02100189-7. 


\section{Abstract}

Background: Human skin color is highly heritable and one of the most variable phenotypic traits. However, the genetic causes and environmental selective pressures underlying this phenotypic variation have remained largely unknown. To investigate whether the pigmentation related-genes polymorphisms are associated with the geographic environmental variables. We selected randomly 795 healthy individuals from eight ethnic groups in nine provinces in China. Six single nucleotide polymorphisms (SNPs) of SLC45A2 and TYR were genotyped using Agena MassARRAY. The chi-square test and Spearman correlation analysis were used to compare the frequency distribution of genotypes among different ethnic groups and evaluate the relationship between SNP genetic diversity and environmental variables, respectively.

Results: The results indicated that rs28777 and rs183671 (SLC45A2) and rs1042602 (TYR) genotype frequency distributions were significantly different between the Xinjiang-Uighur and other ethnic groups $(P<0.05)$. Spearman correlation analysis found that rs28777 $(r=-0.090, P=0.011)$, rs $183671(r=-0.105$, $P=0.003)$, rs 1042602 (r = -0.108, $P=0.002)$, rs1126809 (r=-0.151, $P<0.001)$ allele frequencies were negatively correlated with the longitude; $r 183671(\mathrm{r}=$ $0.151)$, rs1042602 $(r=0.157)$ and $r s 1126809(r=0.138)$ allele frequencies were positively associated with the latitude $(P<0.001)$; rs $183671(r=0.116, P=$ $0.001)$, rs1042602 (r = 0.105, $P=0.003)$ and $\mathrm{rs} 1126809(\mathrm{r}=0.070, P=0.048)$ allele frequencies were positively correlated with the sunshine hours; $r \mathrm{~s} 183671$ ( $\mathrm{r}$ $=-0.076, P=0.033), \mathrm{rs} 1042602(\mathrm{r}=-0.079, P=0.027)$ and $\mathrm{rs} 1126809(\mathrm{r}=-0.076, P=0.031)$ were negatively correlated with the annual average temperature.

Conclusions: Our results confirm the idea that environmental factors have been an important selective pressure upon pigmentation related gene polymorphisms.

\section{Introduction}

Human skin color is highly heritable and one of the most variable phenotypic traits that can vary dramatically within and across ethnic populations [1]. It is known that the human skin color is predominantly determined by pigments include melanin, hemoglobin (red), hemosiderin (brown), carotene (yellow), and bilirubin (yellow) [2]. Among those, the amount, the type, and the distribution of melanin play key roles in determining human skin pigmentation. The studies indicate that the human skin pigmentation in global populations is highly associated with latitude, and fundamentally, the distribution of ultraviolet (UV) radiation $[3,4]$. Moreover, the researchers believe that geographic variation in skin pigmentation was influenced by the concerted action of different types of natural selection, including climate, lifestyle, diet, metabolism [1]. However, the genetic causes and environmental selective pressures underlying this range of skin color variation have remained largely unknown.

With the rapid development of genetics and genomics, researchers have gradually realized that the human skin color diversity is due to the natural positive selection of those genes that impact on human pigmentation, especially in the melanosome biogenesis or the melanin biosynthetic pathways [5, 6]. Recently, a large number of genome-wide association studies (GWAS) for pigmentation have been established and identified that some single nucleotide polymorphisms (SNPs) on TYR, IRF4, TYRP1, OCA2, SLC45A2, MC1R and KITLG genes are significantly associated with human skin color [7-10]. The SLC45A2 (solute carrier family 45 , member 2 ) gene encodes the membrane associated transporter protein (MATP). The SLC45A2 protein expresses in melanocyte cell lines and mediates melanin synthesis by tyrosinase trafficking and proton transportation to melanosomes [11]. SLC45A2 mutations cause oculocutaneous albinism type IV (OCA4) and polymorphisms of this gene are associated with dark skin, hair, and eye pigmentation. [12, 13]. In addition, the $T Y R$ gene encodes tyrosinase, a multifunctional enzyme that plays a major role in melanin biosynthesis in melanocytes [14]. TYR is commonly known as the albino locus since the homozygous or compound heterozygous mutations of this gene result in oculocutaneous albinism type 1 (OCA1), an autosomal recessive genetic disorder characterized by hypopigmented hair, skin and eyes [15].

However, the genetic causes and environmental selective pressures underlying this range of phenotypic variation have remained largely unknown. Therefore, to investigate whether the six polymorphisms (rs11568737, rs28777 and rs183671 in the SLC45A2 gene and rs1042602, rs1393350 and rs1126809 in the TYR gene) are associated with the geographic environmental variables, we selected randomly a total of 795 healthy individuals from eight ethnic groups in nine provinces in China, While collected the geographic environmental variables (altitude, longitude, latitude, and air pressure, sunshine hours, and annual average temperature). The results of the study will increase our understanding of the role of environmental variables in genetic differentiation and maintenance of genetic variation.

\section{Results}

A total of 795 samples including eight ethnic groups from nine provinces in China (Tibet-Tibetan accounted for 13.2\%, Inner Mongolia-Ewenki $12.6 \%$, HainanHan 6.2\%, Ningxia-Hui 12.6\%, Hainan-Li 12.5\%, Inner Mongolia-Mongolian 12.6\%, Guizhou-Miao 11.2\%, Xinjiang-Uighur 13.3\%, and Shaanxi-Han 5.9\%) were collected to study the relationship between skin pigmentation-related gene variants and environmental variables. We also collected the detailed geographical environment information of different ethnic regions, including altitude $(\mathrm{m})$, longitude $\left(^{\circ}\right)$, latitude $\left(^{\circ}\right)$, atmosphere pressure $(\mathrm{kPa})$, sunshine duration $($ hours), and year-round average temperature $\left({ }^{\circ} \mathrm{C}\right)$, as shown in Table 1. 
Table 1

Detailed geographical environment information of different ethnic regions

\begin{tabular}{|c|c|c|c|c|c|c|c|c|}
\hline Ethnic & Residence & $\mathbf{N}$ & $\begin{array}{l}\text { Altitude } \\
(\mathrm{m})\end{array}$ & $\begin{array}{l}\text { Longitude } \\
\left({ }^{\circ}\right)\end{array}$ & $\begin{array}{l}\text { Latitude } \\
\left({ }^{\circ}\right)\end{array}$ & $\begin{array}{l}\text { Atmosphere } \\
\text { pressure (kPa) }\end{array}$ & $\begin{array}{l}\text { Sunshine } \\
\text { duration } \\
\text { (hours) }\end{array}$ & $\begin{array}{l}\text { Year-round average } \\
\text { temperature }\left({ }^{\circ} \mathrm{C}\right)\end{array}$ \\
\hline \multirow[t]{6}{*}{ Tibetan } & Naqu & 4 & 4505 & 92.058 & 31.482 & 58 & 2879 & 11 \\
\hline & Linzhi & 9 & 2994 & 94.368 & 29.655 & 70 & 2005 & 11 \\
\hline & Shannan & 13 & 3572 & 91.78 & 29.243 & 65 & 2800 & 10 \\
\hline & Shigatse & 20 & 3844 & 88.887 & 29.273 & 63 & 3248 & 8 \\
\hline & Lhasa & 59 & 3651 & 91.129 & 29.659 & 64 & 3055 & 10 \\
\hline & Total & 105 & & & & & & \\
\hline \multirow[t]{6}{*}{ Ewenki } & $\begin{array}{l}\text { Ewenki Autonomous Banner } \\
\text { Huisumuhakemugacha }\end{array}$ & 10 & 690 & 119.172 & 48.379 & 93 & 2900 & 3 \\
\hline & $\begin{array}{l}\text { Yiminhe Town, Ewenki } \\
\text { Autonomous Banner }\end{array}$ & 19 & 673 & 119.791 & 48.583 & 93 & 2900 & 3 \\
\hline & $\begin{array}{l}\text { Bayantuohai Town, Ewenki } \\
\text { Autonomous Banner }\end{array}$ & 21 & 617 & 119.762 & 49.143 & 94 & 2900 & 3 \\
\hline & $\begin{array}{l}\text { Dayan Town, Ewenki Autonomous } \\
\text { Banner }\end{array}$ & 23 & 682 & 120.558 & 49.237 & 93 & 2900 & 3 \\
\hline & $\begin{array}{l}\text { Ewenki Autonomous Banner, } \\
\text { Xinihe East Sumu }\end{array}$ & 27 & 788 & 120.3 & 48.867 & 92 & 2900 & 3 \\
\hline & Total & 100 & & & & & & \\
\hline $\begin{array}{l}\text { Hainan- } \\
\text { Han }\end{array}$ & Haikou City, Hainan & 49 & 9 & 110.339 & 20.035 & 101 & 2041 & 24.4 \\
\hline \multirow[t]{4}{*}{ Hui } & $\begin{array}{l}\text { Haiyuan County, Zhongwei City, } \\
\text { Ningxia }\end{array}$ & 5 & 1841 & 105.65 & 36.571 & 81 & 1609 & 11 \\
\hline & Guyuan City, Ningxia & 10 & 1778 & 106.249 & 36.022 & 82 & 1602 & 9 \\
\hline & $\begin{array}{l}\text { Tongxin County, Wuzhong City, } \\
\text { Ningxia }\end{array}$ & 85 & 1316 & 105.816 & 36.986 & 86 & 1690 & 12.5 \\
\hline & Total & 100 & & & & & & \\
\hline \multirow[t]{5}{*}{$\mathrm{Li}$} & $\begin{array}{l}\text { Wangxia Town, Changjiang, } \\
\text { Hainan }\end{array}$ & 5 & 357 & 109.157 & 19.009 & 97 & 2300 & 26 \\
\hline & $\begin{array}{l}\text { Baoting Li and Miao Autonomous } \\
\text { County }\end{array}$ & 8 & 54 & 109.707 & 18.647 & 101 & 2300 & 26 \\
\hline & $\begin{array}{l}\text { Changjiang Li Autonomous } \\
\text { County, Hainan }\end{array}$ & 38 & 140 & 109.062 & 19.304 & 100 & 2300 & 26 \\
\hline & Qicha Town, Changjiang, Hainan & 48 & 107 & 109.062 & 19.118 & 100 & 2300 & 26 \\
\hline & Total & 99 & & & & & & \\
\hline \multirow[t]{3}{*}{ Mongolian } & Chenqiba Town, Inner Mongolia & 19 & 597 & 119.446 & 49.334 & 94 & 3205 & 7.7 \\
\hline & Hohhot & 81 & 1056 & 111.668 & 40.819 & 89 & 2588 & 7.3 \\
\hline & Total & 100 & & & & & & \\
\hline \multirow[t]{3}{*}{ Miao } & $\begin{array}{l}\text { Gaopo Township, Huaxi District, } \\
\text { Guiyang City }\end{array}$ & 39 & 1459 & 106.819 & 26.302 & 85 & 1060 & 14.8 \\
\hline & $\begin{array}{l}\text { Mengguan Township, Huaxi } \\
\text { District, Guiyang City }\end{array}$ & 50 & 1196 & 106.755 & 26.415 & 88 & 1060 & 14.8 \\
\hline & Total & 89 & & & & & & \\
\hline \multirow[t]{5}{*}{ Uighur } & Bazhou & 23 & 944 & 86.152 & 41.77 & 90 & 2990 & 11.5 \\
\hline & Ili & 23 & 646 & 81.331 & 43.923 & 94 & 2977 & 5.8 \\
\hline & Aqsu & 30 & 1109 & 80.314 & 41.15 & 89 & 2911 & 12.5 \\
\hline & Kashgar & 30 & 1298 & 75.996 & 39.476 & 87 & 2760 & 13 \\
\hline & Total & 106 & & & & & & \\
\hline $\begin{array}{l}\text { Shaanxi- } \\
\text { Han }\end{array}$ & Yan'an & 1 & 1070 & 109.496 & 36.591 & 89 & 2056 & 15.5 \\
\hline
\end{tabular}




\begin{tabular}{|c|c|c|c|c|c|c|c|c|}
\hline Ethnic & Residence & $\mathbf{N}$ & $\begin{array}{l}\text { Altitude } \\
(\mathrm{m})\end{array}$ & $\begin{array}{l}\text { Longitude } \\
\left({ }^{\circ}\right)\end{array}$ & $\begin{array}{l}\text { Latitude } \\
\left(\left(^{\circ}\right)\right.\end{array}$ & $\begin{array}{l}\text { Atmosphere } \\
\text { pressure (kPa) }\end{array}$ & $\begin{array}{l}\text { Sunshine } \\
\text { duration } \\
\text { (hours) }\end{array}$ & $\begin{array}{l}\text { Year-round average } \\
\text { temperature }\left({ }^{\circ} \mathrm{C}\right)\end{array}$ \\
\hline & Hancheng & 1 & 457 & 110.449 & 35.483 & 96 & 2056 & 15.5 \\
\hline & Fuping & 2 & 520 & 109.364 & 34.95 & 95 & 2056 & 15.5 \\
\hline & Weinan & 3 & 355 & 109.516 & 34.506 & 93 & 2056 & 15.5 \\
\hline & Xi'an & 40 & 381 & 108.947 & 34.27 & 96 & 2056 & 15.5 \\
\hline & Total & 47 & & & & & & \\
\hline
\end{tabular}

The six SNPs (rs11568737, rs28777 and rs183671 in the SLC45A2 gene and rs1042602, rs1393350 and rs1126809 in the TYR gene) were successfully genotyped from 795 samples (call rate >95\%). The basic information (SNP-ID, chromosome number, position, alleles and gene name) and polymerase chain reaction (PCR) primer sequence (1st-PCRP, 2nd-PCRP and UEP-SEQ) of the six SNPs was showed in Table 2. The MAF and HWE- $P$ value of each SNPs are shown in Supplementary Table 1 and Supplementary Table 2, respectively. The results showed that except for rs 1393350 in $T Y R$ was not in accordance with the HWE in Uighur $(P<0.01)$, other five SNPs were in accordance with the HWE in the nine groups $(P>0.01)$.

Table 2

The basic information and primer sequence of SNPs

\begin{tabular}{|c|c|c|c|c|c|c|}
\hline SNP-ID & Chromosome & Position & Alleles & Genes & 1st-PCRP & 2nd-PCRP \\
\hline rs11568737 & 5 & 33944743 & $\mathrm{~T}>\mathrm{C}$ & $S L C 45 A 2$ & ACGTTGGATGGTGATCACCACGACGACAAC & ACGTTGGATGATGGTGCAGCTGGCTCAG \\
\hline rs28777 & 5 & 33958854 & $\mathrm{C}>\mathrm{A}$ & $S L C 45 A 2$ & ACGTTGGATGAAAAGGCTTCCACTCAGTTG & ACGTTGGATGCAAGAGTCGCATAGGACA \\
\hline rs183671 & 5 & 33964105 & $\mathrm{~T}>\mathrm{G}$ & SLC45A2 & ACGTTGGATGTCCTCATGCATAGACACTCC & ACGTTGGATGATATCCAGGTTGCCTCTGI \\
\hline rs1042602 & 11 & 89178528 & $\mathrm{C}>\mathrm{A}$ & $T Y R$ & ACGTTGGATGTGACCTCTTTGTCTGGATGC & ACGTTGGATGGGTGCTTCATGGGCAAAA \\
\hline rs1393350 & 11 & 89277878 & $\mathrm{G}>\mathrm{A}$ & $T Y R$ & ACGTTGGATGGCATATCCACCAACTCCTAC & ACGTTGGATGGGAAGGTGAATGATAACA \\
\hline rs1126809 & 11 & 89284793 & $G>A$ & $T Y R$ & ACGTTGGATGAATGGGTGCATTGGCTTCTG & ACGTTGGATGCCTCTGCAGTATTTTTGAI \\
\hline
\end{tabular}

In addition, we used the chi-square test to evaluate the difference of genotype frequency distribution of the five SNPs among 8 ethnic groups, as shown in Table 3. The results indicated that the genotype frequency distribution of rs28777 and rs183671 (SLC45A2) and rs1042602 (TYR) were significantly different between the Xinjiang-Uighur and other ethnic groups $(P<0.05)$. The allele frequency distribution of these three significantly different SNPs was shown in Fig. 1. 
Table 3

Differences in genotype distributions of SNPs among different ethnic groups

\begin{tabular}{|c|c|c|c|c|c|c|c|c|c|c|}
\hline SNP-ID & Ethnic & Ewenki & Hainan-Han & Hui & Li & Miao & Mongolian & Tibetan & Uighur & Shaanxi-Han \\
\hline \multirow[t]{9}{*}{ rs28777 } & Ewenki & & & & & & & & & \\
\hline & Hainan-Han & 0.811 & & & & & & & & \\
\hline & Hui & 0.279 & 0.561 & & & & & & & \\
\hline & $\mathrm{Li}$ & 0.977 & 0.897 & 0.323 & & & & & & \\
\hline & Miao & 0.248 & 0.763 & 0.271 & 0.346 & & & & & \\
\hline & Mongolian & 0.778 & 0.998 & 0.353 & 0.887 & 0.614 & & & & \\
\hline & Tibetan & 0.783 & 0.995 & 0.318 & 0.891 & 0.591 & 0.999 & & & \\
\hline & Uighur & $1.12 \mathrm{E}-05$ & $5.32 \mathrm{E}-03$ & $9.27 \mathrm{E}-04$ & 2.87E-05 & $6.78 \mathrm{E}-03$ & 1.65E-04 & $1.09 \mathrm{E}-04$ & & \\
\hline & Shaanxi-Han & 0.617 & 0.557 & 0.209 & 0.617 & 0.278 & 0.560 & 0.576 & 5.02E-04 & \\
\hline \multirow[t]{9}{*}{ rs183671 } & Ewenki & & & & & & & & & \\
\hline & Hainan-Han & 0.416 & & & & & & & & \\
\hline & Hui & 0.366 & 0.545 & & & & & & & \\
\hline & $\mathrm{Li}$ & 0.608 & 0.837 & 0.662 & & & & & & \\
\hline & Miao & 0.503 & 0.322 & 0.155 & 0.401 & & & & & \\
\hline & Mongolian & 0.506 & 0.142 & 0.265 & 0.197 & 0.102 & & & & \\
\hline & Tibetan & 0.575 & 0.784 & 0.301 & 0.797 & 0.620 & 0.098 & & & \\
\hline & Uighur & $3.20 \mathrm{E}-05$ & $5.18 \mathrm{E}-05$ & 4.80E-05 & $3.29 \mathrm{E}-06$ & 1.43E-06 & $2.46 \mathrm{E}-03$ & $2.59 \mathrm{E}-07$ & & \\
\hline & Shaanxi-Han & 0.675 & 0.516 & 0.370 & 0.616 & NA & 0.252 & 0.769 & 2.04E-04 & \\
\hline rs1042602 & Uighur & 3.53E-04 & $3.71 \mathrm{E}-04$ & $4.56 \mathrm{E}-05$ & 3.05E-07 & 1.09E-06 & 4.56E-05 & $2.19 \mathrm{E}-06$ & & $1.58 \mathrm{E}-02$ \\
\hline \multicolumn{11}{|c|}{ SNP: single nucleotide polymorphism } \\
\hline$P<0.05$ wa & onsidered to & significant & & & & & & & & \\
\hline
\end{tabular}

Simultaneously, we analyzed the relationship between SNP genetic diversity and environmental variables using Spearman correlation analysis (Table 4). It was found that the allele frequencies of $r 28777(\mathrm{r}=-0.090, P=0.011), \mathrm{rs} 183671(\mathrm{r}=-0.105, P=0.003), \mathrm{rs} 1042602(\mathrm{r}=-0.108, P=0.002), \mathrm{rs} 1126809(\mathrm{r}=$ $-0.151, P<0.001)$ were negatively correlated with the longitude. However, the positive correlation between the alleles frequencies of $r s 183671$ ( $r=0.151)$, rs1042602 $(r=0.157)$ and $r s 1126809(r=0.138)$ and the latitude were extremely significant $(P<0.001)$. The alleles frequencies of $r s 183671(r=0.116, P=$ $0.001)$, rs1042602 ( $r=0.105, P=0.003)$ and $r s 1126809(r=0.070, P=0.048)$ were found to be significantly positively correlated with the sunshine hours. However, the alleles frequencies of $\mathrm{rs} 183671(\mathrm{r}=-0.076, P=0.033)$, rs1042602 $(\mathrm{r}=-0.079, P=0.027)$ and $\mathrm{rs} 1126809(\mathrm{r}=-0.076, P=0.031)$ were significantly negatively correlated with the annual average temperature. The correlations between the allele frequencies of other SNPs and environmental variables were not significant. These findings indicate that environmental factors have selective pressure on these SNPs.

Table 4

The association between polymorphisms and geographic environmental variables

\begin{tabular}{|c|c|c|c|c|c|c|c|c|c|c|c|c|}
\hline \multirow[t]{2}{*}{ SNP-ID } & \multicolumn{2}{|l|}{ Altitude } & \multicolumn{2}{|c|}{ Longitude } & \multicolumn{2}{|c|}{ Latitude } & \multicolumn{2}{|c|}{ Air pressure } & \multicolumn{2}{|c|}{$\begin{array}{l}\text { Sunshine } \\
\text { hours }\end{array}$} & \multicolumn{2}{|c|}{$\begin{array}{l}\text { Annual average } \\
\text { temperature }\end{array}$} \\
\hline & $Y$ & p & $Y$ & $\mathbf{p}$ & $Y$ & $\mathbf{p}$ & $Y$ & p & $Y$ & $\mathbf{p}$ & $Y$ & $\mathbf{p}$ \\
\hline rs11568737 & 0.038 & 0.286 & -0.031 & 0.383 & -0.007 & 0.851 & -0.037 & 0.302 & 0.010 & 0.783 & 0.011 & 0.748 \\
\hline rs28777 & 0.002 & 0.958 & -0.090 & 0.011 & 0.036 & 0.313 & 0.003 & 0.942 & 0.036 & 0.305 & -0.011 & 0.761 \\
\hline rs183671 & -0.002 & 0.950 & -0.105 & 0.003 & 0.151 & $\begin{array}{l}1.86 \mathrm{E}- \\
05\end{array}$ & 0.006 & 0.872 & 0.116 & 0.001 & -0.076 & 0.033 \\
\hline rs1042602 & 0.004 & 0.903 & -0.108 & 0.002 & 0.157 & $\begin{array}{l}8.54 \mathrm{E}- \\
06\end{array}$ & 0.005 & 0.893 & 0.105 & 0.003 & -0.079 & 0.027 \\
\hline rs1126809 & 0.022 & 0.539 & -0.151 & $\begin{array}{l}1.90 \mathrm{E}- \\
05\end{array}$ & 0.138 & $\begin{array}{l}9.38 \mathrm{E}- \\
05\end{array}$ & -0.015 & 0.666 & 0.070 & 0.048 & -0.076 & 0.031 \\
\hline
\end{tabular}

\section{Discussion}


To investigate whether the pigmentation related genes ( $L C 45 A 2$ and TYR) polymorphisms are associated with the geographic environmental variables (altitude, longitude, latitude, and air pressure, sunshine hours, and annual average temperature), we selected randomly selected 795 healthy individuals from eight ethnic groups in nine provinces in China. The results of this study found that the genotype frequency distribution of rs 28777 and rs 183671 in $S L C 45 A 2$ and rs1042602 in TYR were significantly different between the Xinjiang-Uighur and other ethnic groups $(P<0.05)$. Simultaneously, the rs28777, rs 183671 , rs1042602, rs1126809 polymorphisms were found to be correlated with the geographic environmental variables (longitude, latitude, sunshine hours or annual average temperature).

SLC45A2 (as also AIM1 or MATP) encodes a transporter protein that mediates melanin synthesis, which is expressed in a high percentage of melanoma cell lines. It has been reported that some SLC45A2 mutations cause OCA4 and polymorphisms of this gene were found to be significantly associated with human skin, hair, and eye pigmentation, and its mutation frequency varies significantly among the global population. Yuko Abe et al. found that rs 11568737 in SLC45A2 (T500P) was significantly associated with melanin index [16]. A multi-stage GWAS of natural hair color in European ancestry found that the SNP rs28777 in the SLC45A2 gene was associated with skin color and tanning ability [17]. A large Australian population-based case control study reveal that rs28777 exhibited the strongest crude association with risk of cutaneous malignant melanoma [18]. The rs183671 in the SLC45A2 gene is in strong linkage disequilibrium (LD) with rs16891982 (F374L) in CEU. A previous GWAS declared that the frequency of the rs183671 derived allele increased from Southern to Northern Europe, and this SNP was associated with skin pigmentation, and that each copy of the derived allele lightens the skin by $1.2 \mathrm{M}$ index units [19]. Moreover, a previous GWAS demonstrated that the SNP rs183671 can explain skin color variation in three European studies RS, BTNS, and TwinsUK [20].

TYR is located at human chromosome 11q14.3, and encodes tyrosinase, which regulates the biosynthesis of melanin. Previous studies demonstrated that mutations in TYR can cause OCA1 [15]. The non-synonymous polymorphism rs1042602 (Ser192Tyr) in TYR derived allele has specifically high frequency in Europe, and this SNP was significantly associated with eye color, freckles and lighter skin pigmentation [21-24]. The TYR SNP rs1393350 was found to be associated with human hair, eye and skin color and tanning ability [23, 25-27]. A GWAS of melanoma conducted by the GenoMEL consortium identifies the locus rs 1393350 associated with melanoma risk [28]. The rs 1126809 variant is located in exon 4 of TYR gene and encodes a tyrosinase enzyme with an arginine-to-glutamine substitution at codon 402 (R402Q), and is in LD with rs1393350 [29, 30]. The mutation of rs1126809 (A-G) causes the TYR enzyme to be thermosensitive, thus less active [31]. The rs1126809 has previously been used as a marker for skin pigmentation and also influence brown eye colour formation $[23,30]$. Previous GWAS indicated that the allele A of rs1042602 (TYR) was highly associated with lighter skin color in a South Asian descent population [32]. In has reported that the allele A of rs1042602 was over-represented in the IndoEuropeans population [33]. The two polymorphisms (rs1042602 and rs1126809) in TYR appear at high frequency in Europeans and are largely absent in African populations [34].

This study indicated that the genotype frequency distribution of rs28777 and rs18367 in Xinjiang-Uighur were significantly different from other ethnic groups. Moreover, the allele frequencies of rs28777, rs183671, rs1042602, rs1126809 were negatively correlated with the longitude; rs 183671 , rs 1042602 and rs1126809 allele frequencies were positively associated with the latitude and the sunshine hours, while were negatively correlated with the annual average temperature in Chinese population. At present, there are few research reports on the association between genetic polymorphism and environmental factors. In 2010, Ji et al. [35] found that the disease-predisposition polymorphisms of the melatonin receptors were associated with sunshine duration in the global human populations. These results indicated that environmental factors had selective pressure on these loci, and their changes were related to environmental variables, that is, differences in selection caused by differences in environmental factors play an important role in genetic differentiation.

However, this study has some limitations that cannot be ignored. First, the sample size is small and the statistical power is relatively low. Second, this study is the first to explore the correlation between the allele frequencies of these six SNPs and geographical environmental factors. Third, we only selected 6 SNP loci on two genes to explore their correlation with geographical environmental factors. Finally, this study did not design gene functional experiments to explore how allelic variations at SNPs loci lead to the diversity of skin color phenotypes in the human population. Therefore, we will further collect a larger sample and choose more SNPs and design functional experiments to explore the impact of environmental factors on genetic mutations.

In summary, the results of this study indicate that SLC45A2 and TYR polymorphisms (rs28777, rs183671 and 1042602) were different among different populations. More importantly, our results confirm the idea that environmental factors have been an important selective pressure upon pigmentation related gene polymorphisms (rs28777, rs183671, rs1042602 and rs1126809). Further association and functional studies need to confirm our results in a large sample and explore the influence of geographical environment factors on the skin pigmentation-related genes polymorphisms and the mechanism of action.

\section{Materials And Methods Sample collection}

This study randomly selected a total of 795 healthy individuals from eight ethnic groups in nine provinces in China, including 105 Tibetan individuals, 100 Ewenki individuals, 49 Hainan Han individuals, 100 Hui individuals, 99 Li individuals, 100 Mongolian individuals, 89 Miao individuals, 106 Uighur individuals, and 47 Shaanxi-Han individuals. The basic situation of each population was shown in Table 1. The climate data (sunshine hours and annual average temperature) are quoted from China's surface climate data in 2019. The information of altitude, longitude, latitude, and air pressure was collected through online query. People who have a history of skin pigmentation-related diseases, such as albinism or melanoma were excluded.

\section{Sample collection and DNA extraction}

The peripheral venous blood sample $(5 \mathrm{~mL})$ from each subjects were taken from fasting in the morning using the Ethylene diamine tetraacetic acid (EDTA) tube, and stored at $-20^{\circ} \mathrm{C}$ refrigerator for further experiment. The GoldMag-Mini Whole Blood Genomic DNA Purification Kit (GoldMag. Co. Ltd., Xi'an, China) was used to extract genomic DNA. In order to determine the concentration and purity of the extracted DNA, we use a spectrophotometer (Nanodrop 2000, Thermo Fisher Scientific, Waltham, MA, USA).

Page 6/10 


\section{SNP selection and genotyping}

We randomly selected the six SNPs (rs11568737, rs28777 and rs183671 in the SLC45A2 gene and rs1042602, rs1393350 and rs1126809 in the TYR gene) based on previously published genes related to pigmentation. The online software Agena Bioscience Assay Design Suite Version 2.0

(https://agenacx.com/online-tools/) was used to design the primers sequence (Table 2). The Agena MassARRAY platform (Agena Bioscience, San Diego, CA, USA) was used to genotype the six SNPs from 795 samples, according to the manufacturer's instructions. The data of genotyping results

Genotyping results data management and analysis using the Agena Bioscience TYPER software (version 4.0).

Statistical analysis

We used the Microsoft Excel (Microsoft Corp., Redmond, WA, USA) and Statistical Package for the Social Sciences (SPSS) version 25 (SPSS, Chicago, IL) to perform statistical analysis. The chi-square test was used to evaluate whether each SNP was consistent with Hardy-Weinberg Equilibrium (HWE), and compare whether there are significant differences in the frequency distribution of genotypes among different ethnic groups. The relationship between SNP genetic diversity and environmental variables was analyzed using Spearman correlation analysis. All statistical analyses were two sided and the $P<0.05$ was considered as statistically significant.

\section{Abbreviations}

EDTA

ethylene diamine tetraacetic acid

GWAS

genome-wide association studies

HWE

Hardy-Weinberg Equilibrium

LD

linkage disequilibrium

MATP

membrane associated transporter protein

OCA

oculocutaneous albinism type

PCR

polymerase chain reaction

SLC45A2

solute carrier family 45 , member 2

SNPs

single nucleotide polymorphisms

SPSS

Statistical Package for the Social Sciences

UV

ultraviolet

\section{Declarations}

\section{Ethics approval and consent to participate}

The study design and protocol were approved by the Ethics Committee of the Nanchang University. And the present study was conducted in accordance with the ethical principles of the Declaration of Helsinki. Written informed consent was obtained from all individual participants included in the study.

\section{Consent for publication}

Not applicable.

\section{Availability of data and material}

The data that support the findings of this study are available from the corresponding author upon reasonable request.

\section{Competing interests}

The authors declare that they have no conflicts of interest.

\section{Funding}

Not applicable. 


\section{Authors' contributions}

Yuxin Wang contributed to the study conception and design and data analysis and manuscript writing and provided final approval of the manuscript.

\section{Acknowledgements}

We are grateful to the individuals for their participation in the study. We also thank the staff of the Medical College of Nanchang University who contributed to sample collection for this study.

\section{References}

1. Rocha J. The Evolutionary History of Human Skin Pigmentation. Journal of molecular evolution. 2020;88(1):77-87.

2. Yamaguchi Y, Hearing VJ. Melanocytes and their diseases. Cold Spring Harbor perspectives in medicine 2014, 4(5).

3. Deng L, Xu S. Adaptation of human skin color in various populations. Hereditas. 2018;155:1.

4. Barsh GS. What controls variation in human skin color? PLoS Biol. 2003;1(1):E27.

5. Sturm RA. Molecular genetics of human pigmentation diversity. Human molecular genetics. 2009;18(R1):R9-17.

6. Pavan WJ, Sturm RA. The Genetics of Human Skin and Hair Pigmentation. Annu Rev Genom Hum Genet. 2019;20:41-72.

7. Crawford NG, Kelly DE, Hansen MEB, Beltrame MH, Fan S, Bowman SL, Jewett E, Ranciaro A, Thompson S, Lo Y, et al: Loci associated with skin pigmentation identified in African populations. Science 2017, 358(6365).

8. Jacobs LC, Hamer MA, Gunn DA, Deelen J, Lall JS, van Heemst D, Uh HW, Hofman A, Uitterlinden AG, Griffiths CEM, et al. A Genome-Wide Association Study Identifies the Skin Color Genes IRF4, MC1R, ASIP, and BNC2 Influencing Facial Pigmented Spots. J Invest Dermatol. 2015;135(7):1735-42.

9. Hernandez-Pacheco N, Flores C, Alonso S, Eng C, Mak AC, Hunstman S, Hu D, White MJ, Oh SS, Meade K, et al. Identification of a novel locus associated with skin colour in African-admixed populations. Scientific reports. 2017;7:44548.

10. Adhikari K, Mendoza-Revilla J, Sohail A, Fuentes-Guajardo M, Lampert J, Chacon-Duque JC, Hurtado M, Villegas V, Granja V, Acuna-Alonzo V, et al. A GWAS in Latin Americans highlights the convergent evolution of lighter skin pigmentation in Eurasia. Nature communications. 2019;10(1):358.

11. Fracasso NCA, de Andrade ES, Wiezel CEV, Andrade CCF, Zanao LR, da Silva MS, Marano LA, Donadi EA, Simoes ECC. AL et al: Haplotypes from the SLC45A2 gene are associated with the presence of freckles and eye, hair and skin pigmentation in Brazil. Legal medicine. 2017;25:43-51.

12. Mauri L, Barone L, Al Oum M, Del Longo A, Piozzi E, Manfredini E, Stanzial F, Benedicenti F, Penco S, Patrosso MC. SLC45A2 mutation frequency in Oculocutaneous Albinism Italian patients doesn't differ from other European studies. Gene. 2014;533(1):398-402.

13. Le L, Escobar IE, Ho T, Lefkovith AJ, Latteri E, Haltaufderhyde KD, Dennis MK, Plowright L, Sviderskaya EV, Bennett DC, et al: SLC45A2 protein stability and regulation of melanosome $\mathrm{pH}$ determine melanocyte pigmentation. Molecular biology of the cell 2020:mbcE20030200.

14. Anello M, Fernandez E, Daverio MS, Vidal-Rioja L, Di Rocco F. TYR Gene in Llamas: Polymorphisms and Expression Study in Different Color Phenotypes. Frontiers in genetics. 2019;10:568.

15. Sun W, Shen Y, Shan S, Han L, Li Y, Zhou Z, Zhong Z, Chen J. Identification of TYR mutations in patients with oculocutaneous albinism. Mol Med Rep. 2018;17(6):8409-13.

16. Abe Y, Tamiya G, Nakamura T, Hozumi Y, Suzuki T. Association of melanogenesis genes with skin color variation among Japanese females. J Dermatol Sci. 2013;69(2):167-72.

17. Han J, Kraft P, Nan H, Guo Q, Chen C, Qureshi A, Hankinson SE, Hu FB, Duffy DL, Zhao ZZ, et al. A genome-wide association study identifies novel alleles associated with hair color and skin pigmentation. PLoS Genet. 2008;4(5):e1000074.

18. Duffy DL, Zhao ZZ, Sturm RA, Hayward NK, Martin NG, Montgomery GW. Multiple pigmentation gene polymorphisms account for a substantial proportion of risk of cutaneous malignant melanoma. J Invest Dermatol. 2010;130(2):520-8.

19. Candille SI, Absher DM, Beleza S, Bauchet M, McEvoy B, Garrison NA, Li JZ, Myers RM, Barsh GS, Tang H, et al. Genome-wide association studies of quantitatively measured skin, hair, and eye pigmentation in four European populations. PloS one. 2012;7(10):e48294.

20. Liu F, Visser M, Duffy DL, Hysi PG, Jacobs LC, Lao O, Zhong K, Walsh S, Chaitanya L, Wollstein A, et al. Genetics of skin color variation in Europeans: genome-wide association studies with functional follow-up. Human genetics. 2015;134(8):823-35.

21. Jonnalagadda M, Norton H, Ozarkar S, Kulkarni S, Ashma R. Association of genetic variants with skin pigmentation phenotype among populations of west Maharashtra, India. American journal of human biology: the official journal of the Human Biology Council. 2016;28(5):610-8.

22. Norton HL, Kittles RA, Parra E, McKeigue P, Mao X, Cheng K, Canfield VA, Bradley DG, McEvoy B, Shriver MD. Genetic evidence for the convergent evolution of light skin in Europeans and East Asians. Molecular biology evolution. 2007;24(3):710-22.

23. Sulem P, Gudbjartsson DF, Stacey SN, Helgason A, Rafnar T, Magnusson KP, Manolescu A, Karason A, Palsson A, Thorleifsson G, et al. Genetic determinants of hair, eye and skin pigmentation in Europeans. Nat Genet. 2007;39(12):1443-52.

24. Beleza S, Johnson NA, Candille SI, Absher DM, Coram MA, Lopes J, Campos J, Araujo II, Anderson TM, Vilhjalmsson BJ, et al. Genetic architecture of skin and eye color in an African-European admixed population. PLoS Genet. 2013;9(3):e1003372.

25. Kastelic V, Drobnic K. A single-nucleotide polymorphism (SNP) multiplex system: the association of five SNPs with human eye and hair color in the Slovenian population and comparison using a Bayesian network and logistic regression model. Croatian Med J. 2012;53(5):401-8.

26. Andersen JD, Johansen P, Harder S, Christoffersen SR, Delgado MC, Henriksen ST, Nielsen MM, Sorensen E, Ullum H, Hansen T, et al. Genetic analyses of the human eye colours using a novel objective method for eye colour classification. Forensic science international Genetics. 2013;7(5):508-15. 
27. Nan H, Kraft P, Qureshi AA, Guo Q, Chen C, Hankinson SE, Hu FB, Thomas G, Hoover RN, Chanock S, et al. Genome-wide association study of tanning phenotype in a population of European ancestry. J Invest Dermatol. 2009;129(9):2250-7.

28. Bishop DT, Demenais F, lles MM, Harland M, Taylor JC, Corda E, Randerson-Moor J, Aitken JF, Avril MF, Azizi E, et al. Genome-wide association study identifies three loci associated with melanoma risk. Nat Genet. 2009;41(8):920-5.

29. Hutton SM, Spritz RA. A comprehensive genetic study of autosomal recessive ocular albinism in Caucasian patients. Investig Ophthalmol Vis Sci. 2008;49(3):868-72.

30. Meyer OS, Lunn MMB, Garcia SL, Kjaerbye AB, Morling N, Borsting C, Andersen JD. Association between brown eye colour in rs12913832:GG individuals and SNPs in TYR, TYRP1, and SLC24A4. PloS one. 2020;15(9):e0239131.

31. Jagirdar K, Smit DJ, Ainger SA, Lee KJ, Brown DL, Chapman B, Zhen Zhao Z, Montgomery GW, Martin NG, Stow JL, et al. Molecular analysis of common polymorphisms within the human Tyrosinase locus and genetic association with pigmentation traits. Pigment cell melanoma research. 2014;27(4):55264.

32. Stokowski RP, Pant PV, Dadd T, Fereday A, Hinds DA, Jarman C, Filsell W, Ginger RS, Green MR, van der Ouderaa FJ, et al. A genomewide association study of skin pigmentation in a South Asian population. Am J Hum Genet. 2007;81(6):1119-32.

33. Chaki M, Sengupta M, Mondal M, Bhattacharya A, Mallick S, Bhadra R, Indian Genome Variation C, Ray K. Molecular and functional studies of tyrosinase variants among Indian oculocutaneous albinism type 1 patients. J Invest Dermatol. 2011;131(1):260-2.

34. Sturm RA, Duffy DL. Human pigmentation genes under environmental selection. Genome biology. 2012;13(9):248.

35. Ji LD, Xu J, Wu DD, Xie SD, Tang NL, Zhang YP. Association of disease-predisposition polymorphisms of the melatonin receptors and sunshine duration in the global human populations. Journal of pineal research. 2010;48(2):133-41.

\section{Figures}

rs183671
SLC45A2

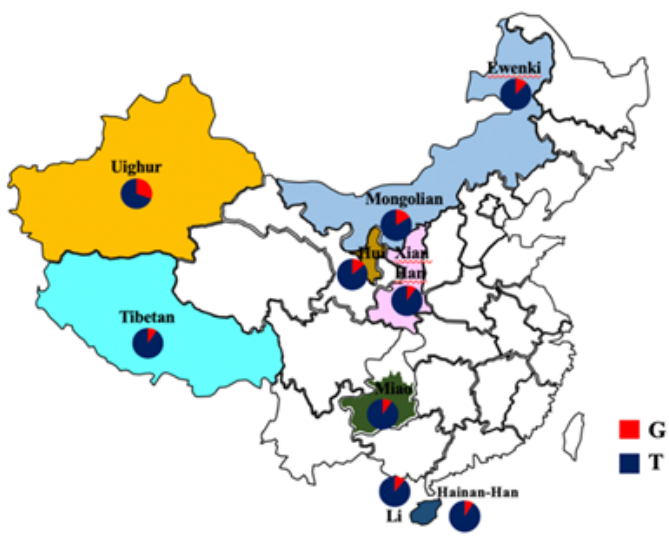

rs28777

SLC45A2

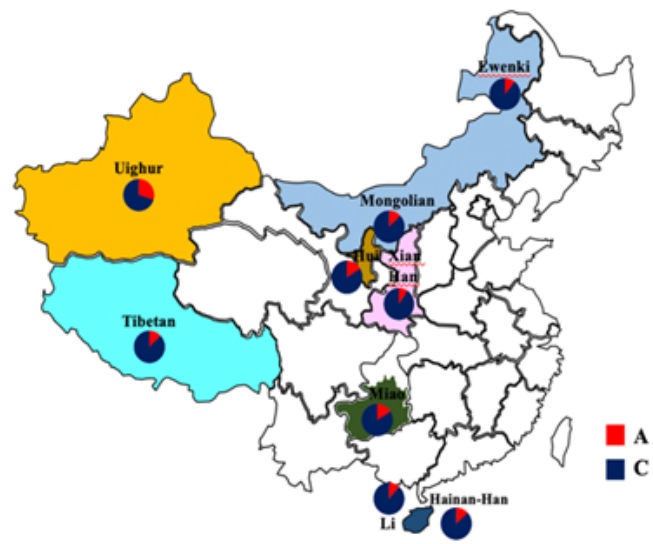

rs1042602

TYR

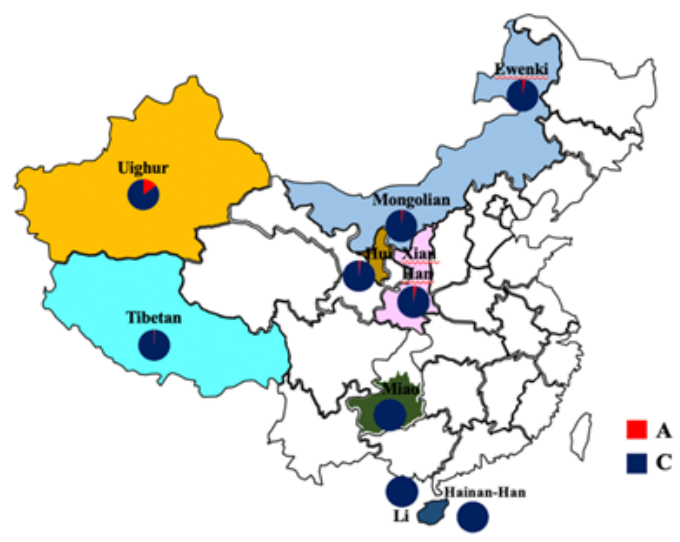

Figure 1

The allele distributions of rs1042602, rs28777 and rs183671 in different Chine population Note: The designations employed and the presentation of the material on this map do not imply the expression of any opinion whatsoever on the part of Research Square concerning the legal status of any country, territory, city or area or of its authorities, or concerning the delimitation of its frontiers or boundaries. This map has been provided by the authors. 
rs183671 SLC45A2

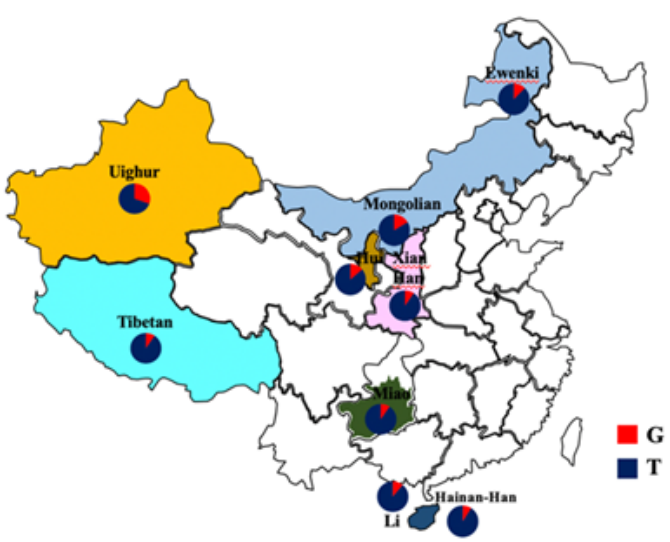

rs28777

SLC45A2

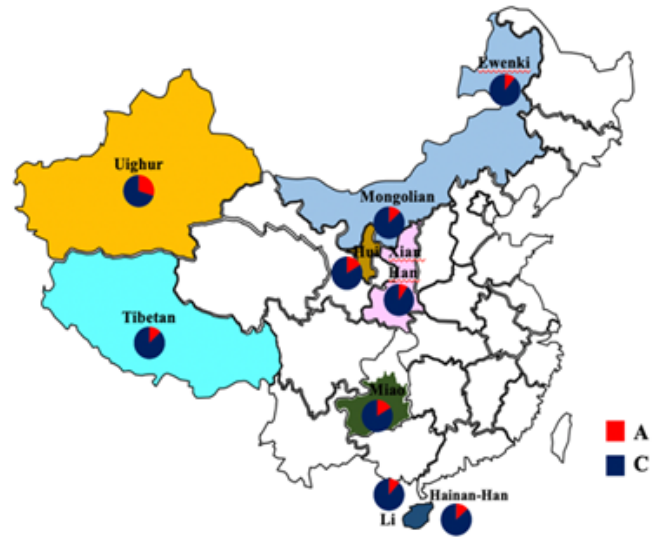

rs1042602

TYR

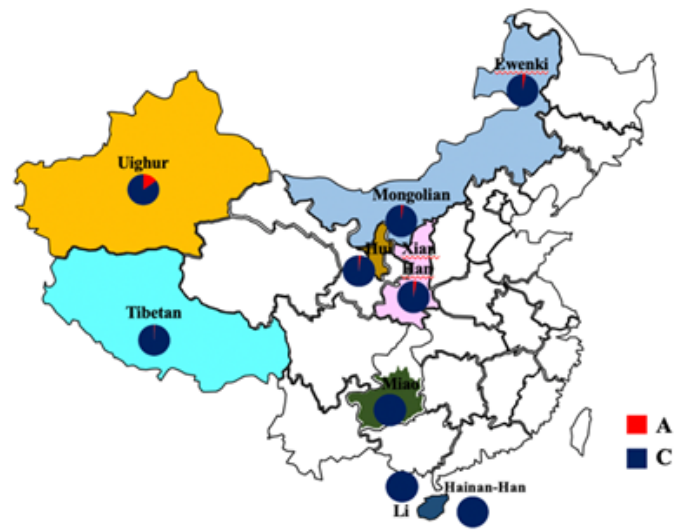

Figure 1

The allele distributions of rs1042602, rs28777 and rs183671 in different Chine population Note: The designations employed and the presentation of the material on this map do not imply the expression of any opinion whatsoever on the part of Research Square concerning the legal status of any country, territory, city or area or of its authorities, or concerning the delimitation of its frontiers or boundaries. This map has been provided by the authors.

\section{Supplementary Files}

This is a list of supplementary files associated with this preprint. Click to download.

- SupplementaryTable.docx

- SupplementaryTable.docx 